\title{
Rolf Thiele's Film Version of Thomas Mann's Homotext Tonio Kröger: A Reconsideration
}

\author{
RALEIGH WHITINGER
}

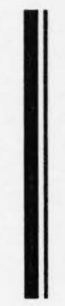

Raleigh Whitinger studied mainly at the University of British Columbia and has taught German literature and language at the University of Alberta since 1972. He has published several articles on modern German literature from Romanticism to the twentieth century, including a monograph on German naturalist dramatist Johannes Schlaf that relates his activities to the homosexual reform movement (1997) and articles and an anthology on Lou AndreasSalomé (2000). His e-mail is rwhiting@ualberta.ca.

$\mathrm{T}$ homas Mann's 1903 novella Tonio Kröger continues to fascinate readers with its account of a young artist whose doubts about his initial success as a man of letters send him journeying homeward. Here he relates once again to the commonplace world of his father with a mixture of ironic distance and loving affection that promises to quicken his work as a mature writer. Yet the 1964 film version of the story, with Rolf Thiele directing a screenplay by Erika Mann and Ennio Flaiano, enjoyed only a brief flurry of mixed reviews (Seitz 453-62) before falling into virtual neglect. Since Gabriele Seitz's 1979 commentary, it has been accorded at best scant, and usually negative attention by scholars (Berlin, "Audiovisual Aids" 25; Kurzke 31; Renner 800). This development is intriguing in the light of the attention that is still accorded Luchino Visconti's 1970 film version of Der Tod in Venedig, and the relative neglect proves questionable when, on reviewing, the earlier film shows itself to be an interesting companion piece to Visconti's illustrious offering. Reconsidered, Thiele's film suggests a reading

torquere: Journal of the Canadian Lesbian and Gay Studies Association / Revue de la Société canadienne des études lesbiennes et gaies Vol. 2 (2000) @ CLGSA / SCELG 
of Mann's text that is in line with recent critical directions that concern - in combination with the text's ironic self-reflection on the artistic narrative's triumph over adversity (Bennett; Kurzke 100-03; Wetzel) - the way it treats the theme of homosexuality (esp. Böhm; Busch; Detering; see also Bridges; Feuerlicht "Homoeroticsm"; Hayman; Heilbut; Jones; Martin; Murfin; Reich-Ranicki; Tobin). I shall support this revised assessment of the film by pursuing two theses regarding two major areas of alteration and invention that the film has undertaken with Mann's text. This will involve consideration, first, of changes that convey more emphatically the original text's subtle hints about the close relationship of the fictive narrator and eponymous hero and, second, of additions that make graphically explicit the original text's indications that homosexuality plays a decisive role in Tonio's struggles as an artist.

Alterations and inventions are a given where film versions of literary texts are concerned. Most discrepancies between the strategy of a filmmaker and a recipient's reading of the original can be assigned to the category of personal taste and pursued mainly to highlight omitted or altered features that might foster new interpretive perspectives. Thiele's film is no exception. Many readers of Tonio Kröger might have welcomed an attempt to capture Thomas Mann's opening with a crane-shot descending through the dismal wintry weather and obscured sun to show Tonio in the Lübeck schoolyard. This might have retained the text's twisted evocation of the classical Homeric epic that the later scenes in Denmark recall when the eponymous hero arises to greet the rosy dawn and go on to his reaffirmation of his position at the edge of life's dancing "sea" (TM 326). ' Other viewers may regret the relative abbreviation of Tonio's sea journey to Denmark, above all since it omits the apparently minor detail of the circus that travels along on the voyage (TM 318). Graphic reference to the "polar bear" and "tiger" that together, from deep in the ship's hold, bellow out against the storm just as Tonio bursts forth with his lyric greeting to the sea (TM 321-22), might have aided the film's efforts to intimate both Tonio's move to harmonize the

'References to Tonio Kröger are to volume VIII of Mann's Gesammelte Werke (see "Works Cited") and are indicated throughout the text by "TM" plus the page number(s) from that volume. Quotations have been translated into English according to the translation by David Luke. 
conflicting voices within himself and the narrative's tendency to such emphatically poetic trumpeting of its own felicitous turns.

Thiele's film also involves instances of streamlining that, while they might strike many as necessary to prevent the film from bogging down in abstract verbosity, are likely to invite critical attack nonetheless. Gabriele Seitz illustrates the degree to which much of the third chapter's commentary on Tonio's progress through immoral adventures to artistic fame has been "compromised" by the film's editorial liberties (432-34). Yet others might be pleasantly surprised by the cuts to Tonio's long exchange with his confidante, the Russian painter Lisaweta Iwanowna, in the fourth chapter. Many might regret the way the concept of "erledigen" (to deal with, take care of) - so important from the fourth chapter onward in enunciating the story's self-ironic perspective on the capacity of the art work to apply an illusory face to complex problems - has been dropped from the story's lexicon of recurring phrases. Yet despite these changes, the film's rendition even of these two dense chapters has preserved some significant phrases. It retains those that refer to Tonio's tendency to "Ausschweifungen" (deviations, eccentricities) in thought and behavior, for example, and others concerning the suspect masculinity of artists (TM 299). These and other changes combine to foster a better understanding of how Mann's text reflects self-ironically on the possibilities and problems of artistic existence arising from the homosexual male's experience of alterity. They shed light on the way the text reflects on its own genesis as the homosexual male's attempt to narrate, with an ironic eye both to the possible missteps and illusions that attend an artful account of real problems and to his own development and triumph as an artist.

Critics have noted two major respects in which Thiele's film departs from the original text. They point out, on the one hand, that events from Tonio's boyhood are presented in the film as flashbacks from the perspective of the mature hero, with several invented scenes added to the portrayal of young Tonio and of the thirty-year-old writer (Seitz 431, 453-62). The sequence depicting young Tonio's walk home with his classmate Hans Hansen has been augmented by scenes in which Tonio interacts with his father and mother. The episodes involving Ingeborg Holm and Monsieur Knaak's dance class are followed by a scene in which the same group of youngsters is shown skating on a lake. As well, the two flashback sequences are embedded 
in invented portrayals of Tonio's southern experiences that, after the narrator has commented on the young man's immoral adventures, involve his interaction with various female figures.

Critics note on the other hand that the film has altered Lisaweta and Tonio's relationship to her. It makes her not only more glamorous but also possessed of romantic feelings for him (Seitz 431, 441-48). This point is made evident in an invented sequence in which Tonio, left alone in Lisaweta's studio while she dashes off to the artists' ball with other bohemians, discovers the cache of sketches that she has made of him. The film also adds a sequence in which Lisaweta bids farewell to Tonio at the train station as he sets out on his journey north, via Lübeck, to Denmark - a cinematic trope suggesting a romantic involvement that travel can only postpone and that only death can prevent. As well, Tonio decides upon this journey immediately after Lisaweta has judged him to be "a bourgeois on the wrong path," and not, as in the text, after a summer of pondering and planning (TM 305). The film's closing sequence takes up this thread of a romance between Tonio and Lisaweta by adding scenes in which Tonio, at peace with himself after the Danish dance sequence, imagines what it would be like if Lisaweta were with him. He imagines this possibility acted out in scenes in which he and Lisaweta embrace on a Danish beach, and she is then shown painting him and debating the various possible personas she should emphasize. Tonio insists that she give him a look of happiness that springs from humane feelings. Adream sequence then shows Tonio dancing with Lisaweta, she in a chiffon negligee, the two of them whirling in a way that recalls the film's rendition of Inge Holm's dance. The last of the imagined Lisaweta episodes has her curled up barefoot on a divan in Tonio's room as he reclines on his bed, smoking. She has just read his manuscript and delivers a critique that he finds too much like that of a wife. The entire imagined reunion sequence ends with Lisaweta suggesting that perhaps Tonio wants her as a friend to whom he can write his perfect letters, not as a vulnerable woman. With this, the 'dream' ends, the image of Lisaweta gone with a gust of wind that also blows Tonio's manuscript pages out the window. He remains on the Danish beach alone, drafting in his mind his letter to Lisaweta. The film ends, like the original text (TM 338), with the lines about the good humor, affection, and innocent bliss that, among other things, fill his living heart. 


\section{4 / Whitinger}

These two main areas of change and invention might strike any viewer as a willful misreading of Mann's text as a sentimental love story, meant to attract a public whom the filmmakers deem unwilling to forego the usual boy-girl romance. First, leading up to Tonio's return to Munich and Lisaweta, the flashback structure and invented scenes of male-female interaction seem to portray Tonio developing through adolescent confusions and toward a romantic commitment, a direction from which Mann's text deviates. Second, from the Lisaweta dialogue onward, the film seems to bracket its loyal rendition of the Lübeck, sea-journey, and Denmark sequence with stations in a contrived liaison between Tonio and Lisaweta. Yet closer consideration of these two major alterations fosters this article's two theses defending the project as a valid interpretation of Tonio Kröger as a self-reflexive homotext.

This article's first thesis holds that the film enhances the original text's ironic intimations about its own narrative authority by emphasizing that the narrator and Tonio are kindred spirits to the point of being identical - and thus that the entire account of felicitous growth is also a self-valorizing account of artistic development to which the third-person conceit lends an illusory aura ofobjective truth. At first glance, this might seem to be a radical departure on the film's part. Mann's text presents young Tonio's development from the perspective of an apparently omniscient narrative authority. The narrator is sympathetic to Tonio and, like him, an artistic type with close ties to the bourgeois world of Lübeck. Yet he remains outside of Tonio, approaching him from on high, filling in exposition, seeing him and his world from the perspective of a sympathetic fellow citizen, although able to reveal and explain the boy's inmost feelings and thoughts. This detachment gives events the sense of unadulterated truth unfolding unmediated before the reader's eyes, conveyed not as an involved figure's artfully embellished recollection, but as the events themselves, rendered with objective immediacy. Not so the film. The events of the text's first two chapters come to the viewer as the recollections of the mature Tonio as he recalls the episodes centered on Hans and Inge. While attending a performance of Giuseppe Verdi's Don Carlos in Ravenna, he looks back on his schoolday walk with Hans and his boyhood enthusiasm for Friedrich Schiller's portrayal of the weeping king. A subsequent passage shows the adult Tonio drawn to a prostitute's room, where a gesture she 
makes initiates his inner replay of scenes with Inge at the dance class and the skating pond. Thus what the text at first seems to offer as the objective truth of Tonio's early stance as a reverent outsider, the film presents as the older Tonio's retrospective reading of his youth, his own nostalgic take on his early stance as an outsider-artist.

Far from distorting Mann's text, however, the film in this way establishes clearly what the original unfolds in subtle detail. It emphasizes the near or total identity of Tonio and the narrator as artists who enact their art's grand but at times illusory triumph over the complexities of life. The closing pages of Mann's text hint emphatically that Tonio has grown to acquire the views, vocabulary, and style of the narrator in the early chapters. When Tonio comes to realize in the eighth and penultimate chapter that he may have "taken the wrong path" (TM 332, gone off "in die Irre") because he had no "right way" (TM 332, "rechten Weg"), he is almost quoting what the narrator had said in the third chapter about young Tonio having "followed the wrong path" (TM 288, "wenn er irreging") because for some individuals there is no "correct way" (TM 288, "richtigen Weg"). When, on the last page of the novella, Tonio ends his letter to Lisaweta with a sentence defending his love of life, he is repeating verbatim, save for the change in verb tense, what the narrator had said at the end of the first chapter about young Tonio's affection for the burghers of Lübeck: "His heart was alive in those days; in it there was longing, and sad envy, and just a touch of contempt, and a whole world of innocent delight" (TM 281, Luke 143; cf. TM 332, Luke 192). By ending with a Tonio who has arguably grown into the narrator who tells his entire story, Mann's text merely gives a parting thrust to its many hints at the narcissism and illusion involved in the narrator's project. Repeatedly, if subtly, the original invites readers to ponder the kinship of Tonio and the narrator and to behold the way they subject complex facts to beautifying transformation. In the opening sequence, the narrator gradually introduces young Tonio as a miniature version of himself, likewise capable, even as a lad, of artistic flights that triumph over the pain of life. The narrator's opening sentences intimate divisions and rifts quite at odds with the untrammeled Apollonian beauty of the Homeric epic that they evoke - the references to sunshine, to the tunic, belt, and footwear of the heroic son, to his relationship on the assembly grounds to the reverent elders deferring to his father's renown clearly allude to the second book of 
the Odyssey, "The Hero's Son Awakens." Yet to that riven world the narrator's art can still impart mythic elements. The sun that shines down here upon the heroic son may be a wan ghost of itself (TM 271), a shadow of the splendor that shines down upon Homer's heroes, its light filtered by a mix of snow and ice that forecasts Tonio's indeterminacy. Yet by the end of the second paragraph, the mythical tie is regained with the description of the teacher's Jovian beard - and augmented by that of his Wodan's hat - while the two heroic "sons" march through the adulatory throngs and into sunlight. Having thus exhibited his own capacity to make sense of the dismal and diverse, the narrator then depicts a Tonio who does likewise even as a boy. Pained by his unrequited love for Hans, Tonio produces not subjective outcries but a well-turned maxim - "Whoever loves the more is at a disadvantage and must suffer" (TM 273) - to convey the "hard and simple truth" of life perceived. Melancholy and alienated, he retreats to his room to fashion well-formed art out of his feelings. He progresses through the Dionysian intimations of music and sea, through his garden vision of nature nurtured and formed, to his verses (TM 273-74). Much as the narrator resorts to Homeric allusion to transform the dismal day of his opening page, Tonio turns to the scene of the betrayed king in Schiller's Don Carlos (TM 277), or to the sleep-versus-dance dilemma of Theodor Storm's poem "Hyazinth" (TM 285, 334), and later still to Shakespeare's Hamlet (TM 300) or to the Bible (TM 338) as sources of comparisons or phrases for describing his situation. Like the narrator, he is ever ready with an artistic turn or structure to impart an aura of poetic beauty and sense to the suffering he experiences.

Besides emphasizing the similarity of these two archly poetic realists, these allusions and citations also intensify the doubts that the original invites about the efficacy of their art. The literary references with which both the narrator and Tonio construct their narratives often evoke precisely those problems that the two would adorn with artful beauty. Contradictions and conflicts of this nature frequently occur between the discourse and story levels of the novella, often in a way that intimates problems of sexual diversity lurking behind the appearance of felicitous development. This is so when the text's allusions to the Bildungsroman tradition also call attention to its title-figure's failure to achieve the 
heterosexual integration that conventionally defines that subgenre. It is evident as well when Tonio's approval of the pure vitality and healthy humor of Scandinavian literature (TM 306) is countered by the text's evocations of Hermann Bang, Hans Christian Andersen, and Henryk Ibsen that focus more on the problems with which Tonio struggles. ${ }^{2}$ Young Tonio's own turns to other works and texts are consistently self-subversive in this respect. His citations of Schiller, Storm, and the Bible, for example, involve, behind their foreground message of his aesthetic skill, signals of the illusory "Erledigung" that covers up the preferably unspoken homoerotic origins of his artistry (TM 299; cf. Detering 309; Wysling, "Dokumente" 58-59). On his homeward walk in the first chapter, Tonio urges Schiller's drama Don Carlos upon Hans Hansen as a work full of political intrigue and gripping scenes. Yet he himself focuses on the weeping king betrayed in an all-male love triangle, thus raising his own suffering with Hans to tragic heights (Böhm 262; Busch 164; Heilbut 161; Tobin 159, 169). In each of the two symmetrically placed dance episodes he recalls the same line from Theodor Storm's poem "Hyazinth": "I long to sleep, to sleep, but you must dance" (TM 285, 334-35). This implies a link between his experiences and the heterosexual longing of that poem. Yet the cited verse and its context apply only tenuously to Tonio's situation (Detering 311-12). He longs to abandon the 'dance' of socially

\footnotetext{
${ }^{2}$ Benjamin Bennett notes the novella's many evocations of the Bildungsroman in particular Novalis's Heinrich von Ofterdingen (cf. Seitz 108-13) and Goethe's Wilhelm Meister. These allusions self-subversively call attention to a point on which the novella's hero deviates from the traditional pattern by not, in contrast to Hegel's definition of the subgenre, 'getting his girl.' Similarly, the narrative's evocations of things Scandinavian as the essence of vital good health refer to works or authors linked to the problems that the story would adorn with art. So it is, for example, with the extended allusion in the dance lesson of the second chapter to the openly homosexual Hermann Bang's Her Royal Highness (esp. Eddy 123-25). Mann's text echoes an episode in Bang's novel, but turns the original's clumsy female dancer into a male dancer so inept that he stumbles "amongst the ladies" and is ridiculed by all as "Miss Kröger" (Detering 311-13). This is also evident in allusions to Hans Christian Andersen and Henryk Ibsen. Tonio's resolve in the eighth chapter to hold to the dangerous "sworddance of art" (TM 334) recalls Andersen's tale of The Little Mermaid (Maar; Detering 314), readable as the Scandinavian author's literary reflections on his own struggle with sexual otherness. And of all possible ways to pay homage to Ibsen, Mann's text elects to use the questions from the late drama When We Dead Awaken about the artist's capacity to participate fully and lovingly in life as a man (TM 296; cf Vaget 107).
} 
acceptable interaction and pairing, also to escape the 'dance' of socially acceptable art that preserves and glorifies that conventional sphere, yearning instead to give himself over to the 'sleep' of desires that draw him away from heterosexual interaction. Even Tonio's magnanimous Bible citation in his closing letter to Lisaweta involves a similar, albeit more esoteric, subtext. He backs up his resolve to love all mankind by quoting I Corinthians 13, 1: "one may speak with the tongues of men and of angels and yet be a sounding brass and a tinkling cymbal" (TM 338). Mann often cited Goethe's use of this same Bible passage in his conversations with Johann Peter Eckermann (25 December 1825) to distance himself from the "loveless" though splendid poetry of the homosexual writer August Graf von Platen (Böhm 263; Busch 126; Kurzke 102-03), a link that renders Tonio's biblical citation a veiled reference to critical deliberations about how a homosexual man should write. Thus in addition to being kindred spirits as artists bent upon making beautiful art of diversity and alterity, Mann's narrator and title-figure are also involved in similar efforts to create narratives that veil homosexuality.

The film emphasizes this close identity of the narrator and the protagonist from early on, repeatedly signaling what the original text nurtures subtly until its final thrust. The film's chronological restructuring of the original text's first three chapters is only the first and most obvious of the means by which it signals that the story about Tonio Kröger unfolding on the screen is in fact Tonio's own third-person account of his moral and artistic triumph over the errant living and questionable aestheticism born of his peripheral position, and thus that the depiction of an artist's conciliation is a self-valorizing fiction of narrator and hero alike. Several additional details portray Tonio to be narrating his own development, writing a story about his life from the perspective of an omniscient third-person narrator in order to give his autobiography an aura of objective authority. No first-time viewer possesses the auditory acuity or foresight to note that the voice of the offscreen narrator who introduces Tonio in Italy is in fact that of Jean Claude Brialy, the actor who plays the mature Tonio. Yet this identity becomes evident in hindsight, hinted at by other details in the film. Once noted, it drives home the correspondence that the original text implies in its closing sentence (see above). The film's opening credits roll against the backdrop of a page from the manuscript of Mann's novella. While otherwise barely 
decipherable, it is clearly about 'Tonio Kröger' and very likely an early version of the passages in the third chapter about Tonio's life in the south. Unfortunately, the final cut of the film deletes from the screenplay a brief shot showing the mature Tonio in his room in Ravenna at work on precisely that page of manuscript. Yet by using the manuscript page at the start, the film announces the existence of a written text about Tonio Kröger, and later scenes remind the viewer that Tonio is making his way from Ravenna back north while working on a manuscript about himself. The film's closing episodes verify this. There, the invented sequence in which Tonio imagines Lisaweta visiting him in Denmark has her reading the manuscript and commenting on how it exposes his life and problems. As well, an intervening scene alters the original in a way that links the same manuscript specifically to Mann's Tonio Kröger. This occurs during Tonio's return to Lübeck, in the episode where the hotel manager and police officer suspect him of being a fugitive embezzler. The filmed version of this episode follows the original text (TM 315-18), with the police officer seizing Tonio's manuscript as proof that he is a writer named Tonio Kröger. Yet in contrast to the original, the film has the police officer read out a sentence of the manuscript. The passage that he reads is identical to the passage in the original text's third chapter that notes how the maturing Tonio came to see in life naught but "comedy and misery" (TM 289-90). This alteration forces the viewer to recognize that the manuscript that Tonio is completing is in fact the story of 'Tonio Kröger' that the film is depicting. Thus the account that he offers of his struggle as an artist back to the productively loving alterity of his early years is also revealed to be a self-valorizing tale that borrows objective authority from its thirdperson conceit.

This article's second thesis holds that the film's invention of scenes portraying Tonio's adventures in Italy and its alteration of his relationship to Lisaweta clarify what the text implies about Tonio's problems in matters of love and sexuality. Above all, these changes enhance the original text's intimations that homosexuality is at the base of the otherness that motors Tonio's turn to art and that guides his efforts to find an artistic stance that makes that alterity aesthetically and morally productive. The film invents scenes and highlights passages retained from the original in a way that raises questions about Tonio's relationships. It then answers them in a way that 
supports readings of the original text as Mann's portrayal of a homosexual male who turns to art to make his status as an outsider function in a creative way. Critics were long inclined to find Tonio's outsider status in his artistic nature. By taking the Inge Holm episodes to signify his passage through a pubescent crisis of homoerotic attraction to Hans Hansen and toward adulation of a young woman and to subsequent romantic adventures as an adult, they were able to liberate the novella from the category of homotext. ${ }^{3}$ Yet the text shows that Tonio's homosexual struggle precedes and determines his artistic activity, and it intimates that this struggle continues to trouble him during his years in the south as a successful man of letters. It also makes clear that the scenes involving Inge Holm, far from signaling a heterosexual turn, instead illustrate how he relates to the 'dance' of proper social relationships as a clumsy misfit prone, as young Tonio in fact does during Monsieur Knaak's lesson, to slip out of place as "Miss Kröger" (TM 285; cf. Detering 306-13).

The restructuring to which the film subjects the scenes of Tonio's early years establishes these points. The Lübeck sequence recalls the tendency of Tonio and the narrator in Mann's text to evoke art works and plot lines that apply a misleading face to the situation. The scene in the opera house has Tonio lost in thought while listening to the aria in Verdi's Don Carlos in which King Philip laments his loveless marriage (see Seitz 435) and then flirting with the beautiful female companion of an elderly man. These heterosexual signals are countered, however, by the fact that Tonio's thoughts take him back to his own unrequited love for Hans Hansen and the way it had recalled the male love triangle of Schiller's play. Clearly, the night at the opera fits not so much into the context of the opera-lover in search of heterosexual romantic adventure, as into that of a mature Tonio recalling the pain of unrequited love that had once fed his creativity.

The events unfolding at the opera might also appear to show a mature Tonio who has moved past his pubescent homoeroticism to

${ }^{3}$ Detering (291) criticizes Joachim Campe's rationale for exluding Tonio Kröger from his anthology on "homosexuality in German literature" and also faults Karl Werner Böhm's view $(111,204,259-60)$ on the significance of Tonio's turn to Inge. James W. Jones uses quotation marks to qualify his admission that Tonio "outgrows" his attachment to Hans (285). The terms "homosexuality" and "homotext" originate with Jacob Stockinger to describe literary texts authored by homosexual writers or depicting homosexual figures (cf. Jones 13-14). 
become an adept player of the romantic field. The young lady in the loge lets fall her kerchief. Tonio picks it up, sniffs it approvingly, and tucks it away in his coat pocket. The next scene has Tonio in the church, apparently about to rendezvous with that flirtatious young woman, who kneels nearby in prayer. Yet Tonio summons her through a mediary. He has another man use the altar as a romantic trysting place and make the surreptitious contact with the dark lady. This he has done so that he himself need only return her kerchief with a silent and delicate gesture. Exotic and erotic adventures there may be in Italy for Tonio - so claims the narrator - but this is not to be one of them. Tonio's interests are directed not at this woman, but rather at another aspect of the Don Carlos drama and at virgins to be worshiped at a distance through art.

The turn suggested here from heterosexual adventure in favor of reverent observation of its aesthetic mediation is also signaled by the treatment of scenes that the screenplay had woven into this sequence, yet dropped from the final version. One of them, immediately preceding the church rendezvous with the opera beauty, has Tonio admiring Antonio Coreggio's painting of "Zeus and Ios," thus acting as charmed observer while a voluptuous female nude is embraced by an ethereal cloud of divine origin (Seitz 425). The reencounter in the church was then to be followed by a sequence in which a brief scene with the woman from the opera stretching out her arms longingly to Tonio is flanked by scenes in which, on the one hand, he looks on as a procession of men kiss an "ecstatically blissful" virgin by Giovanni Bernini and, on the other hand, a Maria procession is preceded by a scene depicting Tonio among other formally attired gentlemen in an establishment populated by lounging courtesans reminiscent of Vittore Carpaccio's paintings (Seitz 425). The lack of information about how Tonio's third brief encounter with the opera flirt was to proceed or what was to happen with the hall full of lounging courtesans makes the speculation about scenes dropped from a work's final version tenuous. Yet the rationale of the changes seems to be directed toward a final version that moves Tonio into a position of observation where conventional erotic adventures are in swing, while also enhancing his tendency to relate to such matters more through the mediating veil of art.

The sequence centering on Tonio's adoration of Ingeborg Holm even more blatantly counters the expectation of conventional romantic 


\section{$92 /$ Whitinger}

activity. Tonio is drawn from his work when a gust of wind blows a page of his manuscript out the window of his Ravenna lodgings and into the square below. Retrieving it, a hesitant Tonio is drawn to a female prostitute who leads him to her nearby room. There, the camera centers on her as she sheds her dark dress to leave herself in white chemise and slip. Yet it shows Tonio reflected in the mirror that hangs on the wall beside her as he sits watching from across the room. He is a study in defensive reserve in his three-piece suit, arms folded, legs crossed. Only as the young woman bends to attend to her footwear does he loosen up and lean toward her and the mirror. Yet this sympathetic and open gesture on his part is directed not at the prostitute, but at the recalled images of Inge and the dance lesson triggered by the young woman's gesture. As she bends over to remove her shoe, Tonio sees in the mirror beside her young Inge in a similar pose before the lesson.

The ensuing flashback involves particularly genial inventions. From dance lesson to skating party, Tonio is shown worshiping Inge from afar, focusing on her face from a distance, yet never in contact, never courting or wooing, never conversing. As in the text, this is quite in contrast to his total 'embrace' of Hans Hansen. In this, the film corresponds to readings of the scenes in Mann's original that, despite the narrator's attempts to camouflage the facts with claims about adolescent Tonio's growth beyond the silly fixations of his boyhood (TM 281-82), note the relative intensity of his attraction to Hans in contrast to his detached reverence for Inge (Detering 29295). The film's two scenes show Tonio hovering ever nearer Inge, yet ultimately unable to connect, left passive and reserved even in the intense moments of intimacy when he adjusts her skate.

By contrast, the dance scene in the film builds a convincing bridge from the mature Tonio's earlier flirtation at the opera to a denouement of his prostitute adventure that drives home his distance from the arena of straight sex. En route to the young hero's dancing faux pas as "Miss Kröger," the film enhances the mirror relationship between Tonio and the flamboyantly third-sex dance master (Martin 60). Knaak offers the youngsters instruction in graceful comportment and the waltz, and then quizzes two boys, the second of them Hans. He then turns to Tonio, the camera following him along the line of boys and drawing in to a closer shot of Knaak and Tonio, face to face. Yet rather than questioning Tonio about the dance, Knaak enacts what 
seems a cryptic ritual of mutual recognition and acknowledgment. As he starts to turn to Tonio, Knaak says to Hans in his affected accent: "Und Ihre Freunde [sic] Kröger, hm, hm" ("And your friend Kröger, hm, hm") - whereby the grammatically incorrect endings on the masculine noun "Freund" seem to assign Hans Hansen a slightly effeminized "friend." Knaak then faces Tonio and, turning away, continues: "Tonio, n'est-ce pas, ... wenn ich mich nicht irre" ("Tonio, n'est-ce pas, ... if I'm not mistaken"), thus verifying Tonio to be, like himself, and likewise by name, a hybrid of the German bourgeois and the exotic, foreign, effeminate - and also prone, perhaps, to "go astray" ("sich irren"). ${ }^{4}$

The scenes that follow develop this relationship between Tonio and Knaak further, with inventions that enhance the original's use of leitmotifs and symmetries. When Knaak chooses Inge to help him demonstrate the proper waltz, Tonio looks on longingly, imagining himself in Knaak's place as Inge's partner. The camera focuses on him as he watches the two, but then shifts to replace Knaak. This conveys Tonio's fantasy of himself taking Knaak's place in Inge's embrace. At the same time it identifies him with the queer Knaak. That identity is emphasized when the dance ends with a vignette that recalls the mature Tonio's opera adventures and drives home their signals about his peripheral relationship to heterosexual activity. As the waltz ends and Tonio's vision fades, Inge drops her handkerchief. Tonio steps forward to retrieve it, a move that recalls the flirtation at the performance of Don Carlos. Yet at the last second, Knaak swoops in to snatch up the young lady's property, return it, and send her over to line up with the other girls. Thus Knaak brings about an echo of the mature Tonio's kerchief-incident in Ravenna. In rapid sequence, Tonio's earlier retrieval and return of a young woman's kerchief is repeated by his revealing mirror image, Knaak.

After the episode with Inge's faulty skate, the clamor of the youngsters in Lübeck blends with the sounds of children playing in the courtyard outside the prostitute's room in Ravenna. The film's return to the mature Tonio seems at first to speak for his move from

${ }^{4}$ Knaak's "sich irren" here can mean "to be mistaken" or also "to go wrong, go astray." It may have been chosen to evoke later passages in the original text where the narrator (TM 288) and then Tonio himself (TM 332) use similar phrases (see above) to refer to Tonio's errant or deviant ways. 
clumsy youth to adroit masculine adulthood. Yet events unfold again in a contrary direction, with the film evoking the original text's motifs of sleep and garden-bound art with some effective inventions. Hours at most have passed since Tonio watched his young companion undress and began to recall Inge. The siesta-hour stillness is disrupted by the children below, and that brief time with the prostitute appears to have been given over entirely to sleep. She is still dressed in slip and chemise, while the dozing Tonio has shed only his vest and jacket, which he retrieves to make a hasty retreat. He tucks a few banknotes under the pillow to recompense the young woman for her time, if not for the intended services. He then avoids further confrontation by scrambling out the window and down into the graveyard. He saunters away, taking pleasure in the classical statuary with its sculpted renditions of sensuous human forms. A brief encounter with the dark beauty of the opera episode drives home the direction of Tonio's interest. It doubles his turn away from the living allure of sultry women and toward the dead or frozen. As she stands at the mausoleum wall, Tonio strides past her, unfazed by the amorous gaze she sends his way before she lowers her veil and places flowers in a niche.

By sleeping through his prostitute encounter to dream of Inge and Knaak, the filmed Tonio evokes the original text's use of the line from Theodor Storm's poem "Hyazinth": "I long to sleep, to sleep, but you must dance" (TM 285, 334). That citation, occurring twice, eventually clarifies how Tonio retains his excluded but loving proximity to the 'dance' of social propriety and acceptable art despite his inmost desire to abandon himself to the 'sleep' of his desires. With his doubled escape from male-female interaction - first from the prostitute, then from opera beauty at the mausoleum - he calls to mind the young Tonio's flight to the violin reveries in his bedroom where he had dreamed of the endless sea and, as a prelude to his verse-making, pondered the garden and fountain visible below (TM 274). Thus what the complex narrative and lengthy dialogue of the original text's third and fourth chapters imply about the deviance of Tonio's sexual adventures and about impulses that might have fostered and informed his turn to art, the film conveys by drawing attention to an absence and then offering visual hints at what fills it. In Mann's text, the third chapter's comments both about Tonio's lack of a right path (TM 288) and about the culpable immorality of his adventures of the flesh (TM 290-91; Detering 295-96) awaken doubts that his 
homosexual tendencies ended with adolescence. Tonio himself fosters such doubts in the fourth chapter. He does so implicitly when he laments his lack of a "friend" (TM 303). That longing evokes, in addition to Thomas Mann's own comments of this time regarding Paul Ehrenberg (Detering 293-94), the similar yearning expressed by King Philip in Don Carlos (Tobin 169). These questions about the orientation of Tonio's mature passionate adventures find still more emphatic support in the original text when he responds evasively to Lisaweta's probing questions about his own first-hand experience with "shocking" aspects of the aesthetic life (TM 299). On the verge of divulging what he knew about some artists whom he had seen thronged by "women and boys," Tonio stops and merely comments that one can learn the most remarkable things about "the origins, accompanying phenomena, and preconditions of artistry" (TM 299). When Lisaweta asks if he has made such remarkable discoveries only about other artists - or also, her question implies, about himself Tonio retreats into thoughtful silence. But the assumptions or suspicions that, in Mann's original, the narrator's comments in the third chapter, Tonio's admissions (TM 299, 303), and Lisaweta's probing question (TM 299) subtly invite, the film emphatically fosters. It has Tonio as the narrator commenting on his own immoral activities in the south, and then it shows such adventures not to involve women. As well, it shores up those assumptions with visual signals that enhance the text's hints at Tonio's ongoing mirror-relationship to the Knaak type. It suggests his lingering preference for relating to conventional sensual pleasure only from a distance and through the mediating veil of the aesthetic.

The escape from the prostitute and, with it, Tonio's entire Italian adventure end with the film's invented confrontation between him and the little girl sorting wild flowers as she sits on the graveyard wall. Tonio passes the girl but then stops and turns. He makes eye contact, nods, and bows, gesturing as if in request. The child tosses him a long-stemmed flower. He picks it up, a dropped offering now retained, and, cropping the stem, fits the flower into his buttonhole before swinging jauntily down the hill, on his way northward to Munich and Lisaweta, and ultimately to his hometown Lübeck and then the Danish coast. With this invention, the film follows the original text's penchant for repetitions and symmetries. And it does this in a way that further hints at how Tonio's relationships to female figures 
is directed not at romantic or erotic adventure, but rather toward realizing his need to regain the status of loving outsider that had quickened his early artistic efforts as a youngster back in Lübeck. By inventing this scene, the film brackets Tonio's conversation with Lisaweta between two encounters with similarly foreign, dark-haired women: on the one hand the flower girl in Ravenna, on the other hand the Danish lass in the eighth chapter's dance episode in whom Tonio sees the echo of Magdalena Vermehren from his early days in Lübeck, his female kindred spirit as a verse-lover and inept dancer, another clumsy "Miss" who had best quit the dance floor (TM 285 and 335; Detering 313-16). The resulting symmetry effectively counters the initial romantic appearances of Tonio's return to Lisaweta by showing how the entire sequence of communicative encounters with women (the flower girl, Lisaweta, the Danish dancer) is meant to involve, rather than the romantic liaisons that the readers of a conventional narrative of Bildungsroman might expect, Tonio's productive awareness of his peripheral relationship to that sphere. Accordingly, while the initial appearance of this flower-girl encounter might suggest that Tonio notes her resemblance to Lisaweta as a darkhaired foreign beauty and thus sets off for Munich, the entire sequence suggests another reading. It evokes Tonio's ties to his father, that pale, fastidious, north German businessman who, in the original text, brought a dark, exotic wife back from southern climes but subsequently lived on in dutiful melancholy, his inclination to the beautiful reduced to the wildflower in the buttonhole of his proper bourgeois suit (TM 274). The Tonio whom the film shows here in full flight from the sultry prostitute and the dark beauty from the opera house mimics his father in this scene. He is once again fastidiously clad and, tucking the flower in his own buttonhole, is likely recalling nostalgically the artistic productivity of that bittersweet distance from the life of his father's sphere. Thus Tonio's prolonged pantomime with the flower-girl graphically intimates insights that come to expression when the clown-clad Lisaweta supplies the essential phrases to spark Tonio's readiness to revisit and reconsider his status as a "bourgeois on the wrong path" (TM 305).

The last six chapters of Mann's text portray Tonio's move to reconciliation with his father's world as an outsider resolved to portray that simple life with angelic tongue and loving heart. They show that development unfolding under the aegis of the woman painter Lisaweta 
Iwanowna. Like Tonio, she is an outsider in the company of German bohemians, and likewise, by her very name, a hybrid of masculine and feminine. She is at first the sympathetic confidante of Tonio's searching deliberations in the fourth chapter, and her "Erledigung" of him plants the seed of his decision to rekindle his closeness to his origins. She is then the recipient of the conciliatory and hopeful letter that marks the end of his story. The film too brackets Tonio's closing turn with episodes centering on Lisaweta and, despite some initially disarming changes, manages to remain consistent with the reading of the original text supported by the changes and inventions discussed so far.

The alterations involving Lisaweta follow the pattern initiated by the scenes that portray Tonio's southern adventures. They pose still more urgently - but then even more provocatively negate - the possibility of a heterosexual relationship. The scenes of flirtation and sexual liaison that accompanied the flashbacks to Hans and Inge had invited expectations of such a direction only to refute them. The changes to the Lisaweta relationship even more emphatically conjure up possibilities of a love interest. Yet these possibilities too the film pursues to a conclusion that is essentially consonant with the original. That Tonio's appearance at Lisaweta's might signify his return to an old flame and thus a further step in his move toward a heterosexual relationship is a possibility that recipients of Mann's text are likely to have forgotten by the time they have completed a first reading. Yet the text plays parodically with romantic stories of Mann's day, echoing their promise of a sexual liaison only then to leave it unfulfilled (Busch 149-51). The film makes much of the romantic reading of the Lisaweta relationship by casting Nadja Tiller as what one commentator has described as a "distractingly beautiful" Lisaweta (Howard), by having her romantically focused on Tonio and then turning up in the closing dream sequences as a possible partner. Having posed this possibility, however, the film then proceeds to refute it. With Lisaweta, the film extends the move from Hans, to Inge, and to the Italian romances that at first glance had suggested a heteronormative progression. Yet it continues to leave such expectations unfulfilled. The central episodes corresponding to the original's third and fourth chapters show Tonio, as in the original, in doubt about his unmanly and deviant inclinations and, in the two mirroring dance-episodes that bracket that center, moving to reaffirm the creative function of this position 
apart from that 'dance'.

As the film moves from Lisaweta's studio to Denmark, it enhances the passages in the original text in which critics have found indications of Tonio's struggle with the taboo nature of the same-sex inclinations at the root of his turn to art. It establishes a progression from the first dancing episode to its echo in Denmark and places them symmetrically around a version of the Lisaweta-dialogue that highlights Tonio's doubts about the "maleness" of artists and their proximity to the castrati (TM 299). With this context established, the enhancement of Lisaweta's imagined role as lover or wife can hardly function other than to pose that reading for the purpose of refuting it and driving home Tonio's deviation from that path. As Tonio imagines this reunion with Lisaweta, he envisions himself as her partner and sees that pairing to be a case of illusory thinking reminiscent of his other turns to art. This is signaled when the Lisaweta whom Tonio imagines painting his portrait responds doubtfully to his desire to be depicted as cheerfully "humane." Doing so, she appropriates a line from Schiller's Don Carlos, suggesting that Tonio is painting a picture of good fortune that he never would or did accord her (see Seitz 446). By adding this Schiller citation, the film contributes to the original text's tendency to pointedly artful symmetries. It also emphasizes the distance of Tonio's own visions from the actual state of affairs in a way that implies a link to his homosexuality. Even the imagined Lisaweta doubts that she will be a part of the warmth that Tonio is ready once more to show toward life. In Tonio's mind, she makes the point by evoking the Schiller play whose male love triangle had occupied Tonio's interest during the days of his friendship with Hans Hansen.

Tonio's ensuing visions of the dance and the bedroom scene emphasize this distance from a romantic liaison. The dance episode recalls the whirling Inge in Knaak's arms, another instance of added symmetry. This time Tonio is positioned differently than before. Then, at the dance lesson, he had imagined himself replacing Knaak to dance with Inge, the camera positioned to capture his perspective as her partner, embraced by Inge and beholding her face as she whirled in his arms. The film thus forces the viewer to identify with Tonio as he imagines his own identity with Knaak. The dance with Lisaweta, however, he imagines from outside, seeing himself as her partner. The shift suggests a detachment on Tonio's part from the vision of 
his dancing with Lisaweta. His dream observes their dance from outside, without, as with Inge, positioning Tonio as her embraced partner. This change also suggests his focus in this late dance episode to be more on himself as a possible dancing partner rather than on the female object of his adulation. The bedroom scene that follows evokes a traditional pattern that, by moving from embrace-scene to post-embrace boudoir conversation, implies the unseen sex-scene between the two. Yet this scene too veers away from that direction when the reference to wifely-sounding criticism leads to Lisaweta's termination of the bedroom liaison with remarks that imply the unlikelihood of her enduring a relationship with Tonio that would remain on the intellectual level. Accordingly, the film ends more like the original text than in contrast to it. More emphatically than the text, it raises the possibility of a romantic relationship. Yet it does so to underline the distance from that path that is essential to Tonio's alterity and that he now once again is able to make aesthetically productive in a way morally well-disposed to the conventional world.

Limited resources and, in 1964, a still greater reticence about the role of sexual diversity in Thomas Mann's works appear to have combined to hinder critical recognition of how, with the two main areas of change that this paper has outlined, the film Tonio Kröger captures the original text's use of sexual otherness as a point of departure for reflecting ironically on the artist's capacity to make sense of the ineluctable antitheses of human existence. The film was made just when specialists were beginning to discover and respond to documents indicating that Mann's own struggle with homosexuality left their mark on his 1903 text (Böhm 31; Detering 293-95). Erika Mann was involved in those revelations while she was making her contribution to the film. On the one hand, she consulted with Ennio Flaiano on his Italian screenplay, and she is credited as the major writer on the German version (Seitz 415-16). On the other hand, she was editing, for the Fischer publishing house, the 1965 edition of her father's letters that for the first time included, as an appendix, the long unknown letters to Paul Ehrenberg that concern Mann's homosexual attraction and at times resemble passages in the novella. This coincidence does much to explain why the film adds episodes and highlights others in a way that emphasizes the hero's deviation from the typically masculine and heteronormative, the way it poses the possibility of conventional romance only to counter it with 
indications of a different orientation. The changes reflect the discovery of this aspect of the text's genesis and background. Unfortunately, however, the film appeared at a time of still greater public aversion to discussing homosexuality or attributing it to a revered author. As well, it lacked the high-profile star power, the directorial cachet, and the production values (Seitz 416) to guarantee, as those elements have repeatedly done for Visconti's Death in Venice, the process of recurring critical reconsideration that might have established its significance as an early document of Mann-reception's response to the new revelations about the genesis, context, and text of Tonio Kröger. Consequently, the meaningful changes born of Erika Mann's involvement both with the screenplay and with the Ehrenberg letters were passed over in silence, never revisited, and the film was thus consigned to an oblivion from which neither Gabriele Seitz's study, nor the video release of 1983 , nor the occasional cinephile (Howard) have been able to rescue it. It long remained one of a group of events since the 1960 s that produced a brief public sensation about Thomas Mann as an erotic author of scandalously deviant bent, yet found little resonance in the secondary literature (Böhm 31). ${ }^{5}$ Nevertheless, the growing tendency since the late 1980 s to address the sexual problems of the original story's genesis and text clearly justifies the reconsideration of the film proposed here. ${ }^{6}$ For noteworthy indeed is the way that the film's two main areas of change and invention combine to retain a loyalty to the original text's focus not simply on the diversely

\footnotetext{
${ }^{5}$ This would include the Ehrenberg letters and the 1965 revelations from the unpublished notebooks (Wysling, "Aschenbacks Werke"), the 1965 film version of the Wälsungenblut ("Blood of theWälsungs"; also directed by Rolf Thiele), the 1964 opera Death in Venice involving the collaboration of Benjamin Britten and Peter Pears, the discovery in 1965 of Wladyslaw von Moes as the real Tadzio (Doegowski), and the 1971 film version of Death in Venice.

'In his 1982 article, Ignace Feuerlicht finds the position of his 1966 monograph too cautious in light of the subsequently published letters and notebooks. He goes on to criticize the tendency of Mann's critics and biographers (e.g., Peter de Mendelssohn) to evade the topic of homoeroticism in the face of those documents, a sentiment that Ronald Hayman intensifies in his 1995 biography (63; cf. Tobin 226). The ensuing contributions by Böhm, Bridges, Busch, Detering,Gullette, Härle, Hayes/Quinby, Jofen, Jones, Maar, Martin, Oosterhuis, Reich-Ranicki, Tobin, and Wysling/Schmidlin constitute a positive response to these calls for change. None of them addresses the Tonio Kröger film.
} 
sexual nature of the protagonist's alterity but also on the capacity of his artistic activity to make that problem productive. Like the original text, the film foregrounds an idealistic view of the conciliatory potential of the artist's peripheral position. Yet by portraying Tonio as the author of his own success story the film echoes the text's acknowledgment of its link to the facile "Erledigung" that Tonio criticizes at his turning point. It resembles the text by depicting an unusual male protagonist whose story mimics, yet alters the pattern of the Bildungsroman. Yet at the same time it signals the high degree of poetic embellishment, the prominent role of self-valorizing narrative and facile aesthetic dispatch to which that solution owes its artful existence.

\section{Works Cited}

Berlin, Jeffrey B., ed. Approaches to Teaching Mann's Death in Venice and Other Short Fiction. New York: MLA, 1992.

—. "Audiovisual Aids." Berlin, Approaches 24-26.

Bennett, Benjamin. "Casting out Nines: Structure, Parody, and Myth in 'Tonio Kröger.'” Revue des langues vivantes 42 (1976): 12646.

Böhm, Karl Werner. Zwischen Selbstzucht und Verlangen: Thomas Mann und das Stigma Homosexualität. Würzburg: Königshausen \& Neumann, 1991.

Bridges, George Byron. "Homoeroticism and the Father-Son Relation in the Principal Works of Herman Melville and Thomas Mann." Diss. University of Illinois, Urbana-Champaign, 1983.

Busch, Frank. August Graf von Platen-Thomas Mann: Zeichen und Gefühle. Munich: Fink. 1987.

Campe, Joachim. Andere Lieben. Homosexualität in der deutschen Literatur. Ein Lesebuch. Frankfurt/M.: Suhrkamp, 1988.

Detering, Heinrich. Das offene Geheimnis. Zur literarischen Produktivität eines Tabus von Winckelmann bis zu Thomas Mann. Göttingen: Wallstein, 1994.

Doegowski, Andrzej. "Ich war Thomas Manns Tadzio.” twen 7 (1965): 10.

Eddy, Beverly Driver. "Teaching Tonio Kröger as Literature about Literature.” Berlin, Approaches 119-25. 
Feuerlicht, Ignace. Thomas Mann und die Grenzen des Ich. Heidelberg: Winter, 1966.

—. "Thomas Mann and Homoeroticism." Germanic Review 57 (1982): 89-97.

Gullette, Margaret Morganroth. "The Exile of Adulthood Pedophilia in the Midlife Novel." Novel: A Forum on Fiction 17 (1984): 215-32.

Härle, Gerhard. Männerweiblichkeit: Zur Homosexualität bei Klaus und Thomas Mann. Frankfurt/M: Athenäum, 1988.

Hayes, Tom, and Lee Quinby. "The Aporia of Bourgeois Art Desire in Thomas Mann's Death in Venice." Criticism: A Quarterly for Literature and the Arts 31 (1989): 159-77.

Hayman, Ronald. Thomas Mann. A Biography. New York: Scribner, 1995.

Heilbut, Anthony. Thomas Mann. Eros and Literature. New York: Knopf, 1996.

Howard, Jim. "Tonio Kröger (1964). Brief Comment." The Internet Movie Database. <http://www.imdb.com>.

Jofen, Jean. "A Freudian Commentary on Thomas Mann's Death in Venice." Journal of Evolutionary Psychology 6 (1985): 238-47. Jones, James W. "We of the Third Sex." Literary Representations of Homosexuality in Wilhelmine Germany. New York: Lang, 1990. Kurzke, Hermann. Thomas Mann. Epoche-Werk-Wirkung. Munich: Beck, 1985.

Lorey, Christoph and John L. Plews. Queering the Canon. Defying Sights in German Literature and Culture. Columbia: Camden, 1998.

Luke, David, trans. Death in Venice and Other Stories. By Thomas Mann. New York: Bantam, 1988.

Maar, Michael. Geister und Künste. Geheimnisse des "Zauberbergs." Munich: Hanser, 1995.

Mann, Erika, ed. Thomas Mann Briefe 3. 1948-1955 und Nachlese. Frankfurt/M: Fischer, 1965.

Mann, Thomas. Gesammelte Werke in Zwölf Bänden. Oldenburg: Fischer, 1960.

- Tonio Kröger. Adaptation for the screen by Erika Mann and Ennio Flaiano. With Jean-Claude Brialy, Nadja Tiller, and Gert Fröbe. Sandy Hook: Video Yesteryear, 1983.

Martin, Robert K. “Gender, Sexuality, and Identity in Mann's Short 
Fiction.” Berlin, Approaches 57-67.

Mendelssohn, Peter de. Der Zauberer. Das Leben des deutschen

Schriftstellers Thomas Mann. Vol. I. Frankfurt/M: Fischer, 1975. Murfin, Ross C. "Gender Criticism in Death in Venice." Ritter 21125.

Oosterhuis, Harry. "The Dubious Magic of Male Beauty: Politics and Homoeroticism in the Lives and Works of Thomas and Klaus Mann.” Lorey \& Plews 181-206.

Reich-Ranicki, Marcel. Thomas Mann und die Seinen. Frankfurt/M: Suhrkamp, 1989.

Renner, Rolf Günter. "Verfilmungen der Werke Thomas Manns."

Thomas-Mann-Handbuch. Ed. Helmut Koopmann. Stuttgart: Kröner, 1990. 799-822.

Ritter, Naomi, ed. Thoms Mann. Death in Venice. Complete, Authoritative Text with Biographical and Historical Context, Critical History, and Essays from Five Contemporary Critical Perspectives. Boston: Bedford, 1998.

Seitz, Gabriele. Film als Rezeptionsform von Literatur. Zum Problem der Verfilmung von Thomas Manns Erzählungen "Tonio Kröger," "Wälsungenblut" und "Der Tod in Venedig." Munich: tuduv, 1979.

Stockinger, Jacob. "Toward a Gay Criticism." College English 36 (1974): 303-10.

—. "Homotextuality: A Proposal." The Gay Academic. Ed. Louie Crew. Palm Springs: ETC, 1978. 135-51.

Thiele, Rolf, dir. Tonio Kröger. Adaptation for the screen by Erika Mann and Ennio Flaiano. With Jean-Claude Brialy, Nadja Tiller, and Gert Fröbe. Sandy Hook: Video Yesteryear, 1983. [Originally: Göttingen, Munich, Paris: Seitz-Filmaufbau, Procinex, 1964]

Tobin, Robert. “Thomas Mann's Queer Schiller.” Lorey \& Plews 15980.

- "The Life and Works of Thomas Mann: A Gay Perspective." Ritter 225-44.

Vaget, Hans Rudolf. Thomas Mann: Kommentar zu sämtlichen Erzählungen. Munich: Winkler, 1984.

Visconti, Luchino, dir. Death in Venice. With Dirk Bogarde. Burbank: Warner Home Video, 1984. [Originally: Rome, Paris: Alfa cinematographica, Cinematographique Francaises, 1971.]

Wetzel, Heinz. "Erkenntnisekel. Motivkorrespondenzen zwischen 
104 / Whitinger

Heines 'Götterdämmerung' und Thomas Manns 'Tonio Kröger.' Heine-Jahrbuch 20 (1981): 163-69.

Wysling, Hans. "Aschenbachs Werke. Archivalische Untersuchungen an einem Thomas Mann-Satz." Euphorion 59 (1965): 272-314. ---. "Dokumente zur Entstehung des 'Tonio Kröger."” Quellenkritische Studien zum Werk Thomas Manns. Ed. Paul Scherrer and Hans Wysling. Bern: Francke, 1967. 46-83.

— and Yvonne Schmidlin, eds. Thomas Mann. Notizbücher. 7-14. Frankfurt/M.: Fischer, 1992.

$\tau$ 